\title{
BENTUK, PENYEBAB, DAN DAMPAK DARI TINDAK KEKERASAN GURU TERHADAP SISWA DALAM INTERAKSI BELAJAR MENGAJAR DARI PERSPEKTIF SISWA DI SMPN KOTA SURABAYA: SEBUAH SURVEY
}

\author{
Tamsil Muis, Muhammad Syafiq, dan Siti Ina Savira \\ Jurusan Psikologi Pendidikan dan Bimbingan Universitas Negeri Surabaya \\ e-mail: inasavira@yahoo.com
}

\begin{abstract}
Abstrak: Penelitian ini bertujuan untuk mengetahui deskripsi kuantitatif dari bentuk, penyebab, dan dampak dari tindak kekerasan guru terhadap siswanya dalam interaksi belajar mengajar berdasarkan perspektif siswa. Studi pendahuluan dilakukan dengan melakukan wawancara terhadap Pengawas Sekolah Kota Surabaya, untuk mendapat rekomendasi mengenai lokasi penelitian yang dianggap sesuai. Lima Sekolah Menengah Pertama Negeri (SMPN) di wilayah Kota Surabaya dipilih berdasarkan rekomendasi tersebut. Penelitian ini merupakan penelitian survey. Pengumpulan data dilakukan dengan menyebar angket terhadap 210 subyek yang menjadi sampel penelitian dari 5 lokasi penelitian. Angket tersebut terdiri dari 36 item pertanyaan dan pernyataan tertutup yang dikembangkan oleh tim peneliti mengenai bentuk, penyebab, dan dampak dari tindak kekerasan yang pernah menimpa siswa. Hasil survey menunjukkan bahwa bentuk kekerasan yang muncul adalah kekerasan verbal sebesar 32,6\%; psikologis sebesar 46,1\%; dan fisik sebesar 12,4\%. Penyebab dari tindak kekerasan tersebut antara lain dipicu kesalahan siswa $(29,2 \%)$, temperamen guru $(2,2 \%)$, serta alasan yang tidak diketahui siswa $(11,8 \%)$, dan lain-lain yang sebagian besar juga merujuk pada perilaku siswa $(35,4 \%)$. Dampak dari tindakan tersebut antara lain perasaan minder $(2,8 \%)$, marah $(48,9 \%)$, sedih $(5,1 \%)$, ingin balas dendam $(0,6 \%)$, dan sakit hati $(38,2 \%)$. Selain itu, diketahui bahwa $24,7 \%$ siswa yang melaporkan pernah mengalami tindak kekerasan dalam berbagai bentuk adalah laki-laki, sementara siswa perempuan sebesar $64,9 \%$.
\end{abstract}

Kata kunci: Kekerasan dalam interaksi belajar mengajar.

Pendidikan anak seringkali tidak lepas dari tindak kekerasan. Bentuk-bentuk kekerasan yang dilakukan pada anak dapat bermacam-macam, mulai verbal hingga fisik. Di Indonesia angka kekerasan terhadap anak secara umum semakin meningkat. Lembaga Perlindungan Anak (LPA) di Jawa Tengah melaporkan sepanjang Januari-Nopember 2003 terdapat 285 kasus kekerasan dan eksploitasi atas anak, seorang diantaranya meninggal. Di Sulawesi Selatan pada periode yang sama tercatat 187 kasus kekerasan terhadap anak, $37 \%$ diantaranya berupa kekerasan seksual dan $19 \%$ kekerasan fisik (Kompas, 27 Juli 2005).

Fenomena tersebut semakin memprihatinkan, sebab tindak kekerasan juga terjadi di sekolah, yang merupakan lembaga pendidikan dimana orangtua mempercayakan anak-anak mereka untuk mendapat pendidikan. Tindak kekerasan tersebut dapat dilakukan oleh guru dan kerap dianggap sebagai bagian dari pendidikan ataupun pembentukan perilaku. Hasil penelitian Unicef di Jawa Tengah, Sulawesi Selatan, dan Sumatera Utara pada tahun 2006 menunjukkan bahwa kekerasan terhadap anak sebagian besar, hampir $80 \%$, dilakukan oleh guru (Jawa Pos, 20 Nopember 2007). Data yang diperoleh oleh Komisi Perlindungan Anak Indonesia (KPAI) dari laporan masyarakat dan pemberitaan media massa juga menunjukkan peningkatan tindakan kekerasan guru terhadap siswa secara signifikan, yakni 39\% dari 95 kasus kekerasan yang terjadi selama Januari hingga April 2008 (Kompas, 5 Juni 2008). Prosentase ini meningkat jika dibandingkan dengan data KPAI tentang kekerasan guru pada siswa pada tahun 2007 yang mencapai 11,3\%. KPAI juga 
mencatat bahwa selama dua tahun terakhir, yakni tahun 2007 dan 2008, korban terbanyak selalu berasal dari siswa SD dan SMP.

Hasil dengan kecenderungan serupa dapat dilihat dari hasil penelitian yang dilakukan oleh Yayasan Sejiwa tentang kekerasan di tiga kota besar di Indonesia yaitu Yogyakarta, Surabaya, dan Jakarta, yang mencatat terjadinya tingkat kekerasan sebesar $67,9 \%$ di tingkat sekolah menengah atas (SMA) dan 66,1 di tingkat sekolah lanjutan pertama (SMP) (Media Indonesia, 1 Juni 2008).

Kasus kekerasan di sekolah juga telah banyak diliput media massa. Seorang guru olahraga SMP di Surabaya menghukum seorang siswa yang terlambat datang ke sekolah dengan berlari beberapa kali putaran. Namun karena fisiknya lemah, sang siswa akhirnya meninggal dunia (Jawa Pos, 17 Oktober 1997). Di Riau, seorang guru SD menghukum muridnya dengan berlari keliling lapangan dalam kondisi telanjang bulat (Jawa Pos, 25 April 2002). Media Indonesia (28 Nopember 2006), memberitakan bahwa di Sulawesi Selatan ada seorang siswa SMA meninggal akibat lemparan batu yang mengenai kepalanya oleh seorang guru olahraga. Tiga orang siswa SMKN 1 Gempol Pasuruan melaporkan wakil kepala sekolah mereka ke polisi dengan tuduhan melakukan penganiayaan (Seputar Indonesia, 8 Agustus 2008).

Beberapa asumsi bisa diajukan untuk menjelaskan fenomena kekerasan yang terjadi dalam dunia pendidikan. Pertama, kekerasan dalam pendidikan bisa muncul sebagai akibat adanya pelanggaran yang disertai dengan hukuman, terutama fisik. Ada pihak yang melanggar dan ada pihak yang memberi sanksi. Bila sanksi melebihi batas atau tidak sesuai dengan kondisi pelanggaran, maka terjadilah tindak kekerasan. Aksi kekerasan susulan bisa terjadi bila antara pelaku dan korban terjadi aksi saling balas-dendam. Tawuran antar-pelajar atau antar-mahasiswa merupakan contoh kekerasan ini.

Kedua, kekerasan dalam pendidikan bisa diakibatkan oleh buruknya sistem dan kebijakan pendidikan yang berlaku. Muatan kurikulum, yang hanya mengandalkan kemampuan aspek kognitif dan mengabaikan aspek afektif, menyebabkan berkurangnya proses humanisasi dalam pendidikan. Ketiga, kekerasan dalam pendidikan mungkin pula dipengaruhi oleh lingkungan masyarakat dan tayangan media massa. Penelitian-penelitian yang telah ada menunjukkan bahwa kecenderungan media massa dalam memberitakan aksi kekerasan dapat mempengaruhi perilaku pemirsanya. Keempat, kekerasan bisa jadi merupakan refleksi dan perkembangan kehidupan masyarakat yang mengalami pergeseran cepat, sehingga meniscayakan timbulnya sikap instant solution dan jalan pintas. Kelima, kekerasan mungkin pula dipengaruhi oleh latar belakang sosial-ekonomi pelaku.

Faktor pertama dan kedua mungkin manifestasi dari kondisi internal pendidikan, sedangkan faktor ketiga sampai kelima merupakan kondisi eksternal pendidikan. Hubungan kedua kondisi kekerasan beserta indikatornya, dapat diilustrasikan pada Skema 1.

Skema 1: Faktor-faktor Terjadinya Kekerasan dalam Pendidikan

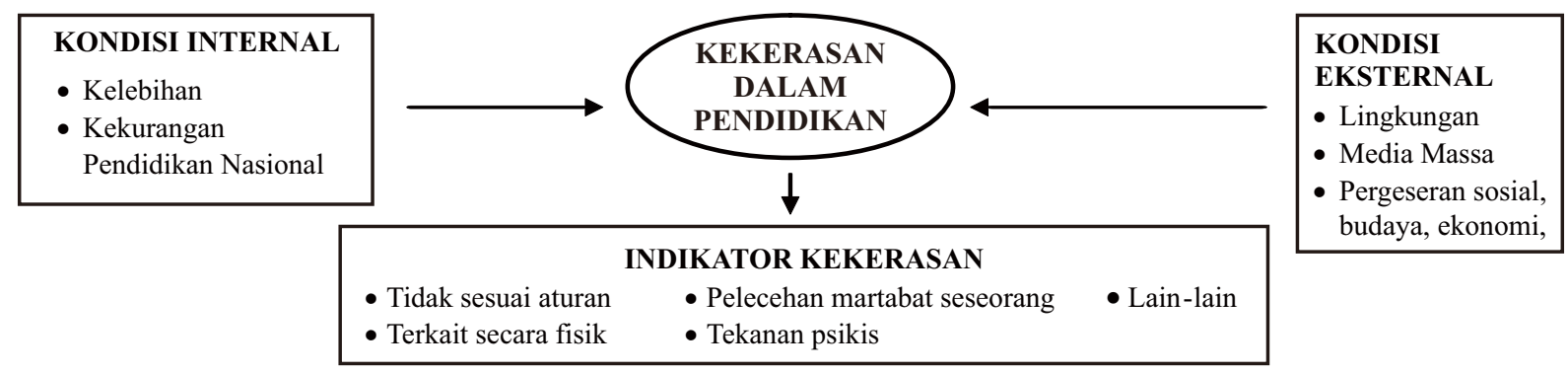


Covey (1998) mengungkapkan bahwa setidaknya terdapat dua pemicu kemunculan kekerasan dalam interaksi belajar mengajar terhadap siswa. Pertama, pemicu dari dalam yang berupa prakarsa guru. Tindakan yang dipicu oleh prakarsa guru biasanya sebelum muncul telah direncanakan terlebih dahulu. Kedua, pemicu dari luar yang berupa perilaku siswa. Tindakan yang muncul karena dipicu oleh perilaku siswa, biasanya bersifat kreatif sehingga belum direncanakan karena kemunculan serta sifat perilaku siswa sangat kontekstual.

Adapun kekerasan atau agresi, umumnya didefinisikan dengan menekankan pada bentuk dan tujuan dari perilaku tersebut. Berkowitz (1995:4) mendefinisikan agresi sebagai bentuk perilaku yang dimaksudkan untuk menyakiti seseorang baik secara fisik maupun mental. Selain itu Steinmetz (dalam Kashani dkk., 1991:218) juga menyatakan bahwa agresi adalah tindakan yang menggunakan kekuatan fisik dan verbal untuk mencapai suatu tujuan tertentu melalui konflik. Tingkah laku agresi ini pada dasarnya merupakan tingkah laku yang bertujuan untuk melukai, menyakiti atau merugikan orang lain (Baron \& Graziano, 1991:312). Baron (1996:347) menambahkan bahwa agresi adalah tingkah laku individu yang ditujukan untuk melukai atau mencelakakan individu lain yang tidak menginginkan datangnya tingkah laku tersebut.

Ada tiga perspektif teoritis berbeda tentang penyebab kekerasan manusia, yaitu bersifat instingtif, semata-mata hasil belajar, dan respons innate yang didorong oleh frustrasi (Gilligan, 1996). Teori insting tentang kekerasan, diantaranya ditulis Freud (1953) tentang dorongan bagi tindakan destruktif terhadap insting yang mati dan tulisan Lorenz (1971) tentang agresi sebagai insting yang meningkatkan ketahanan hidup, mengasumsikan bahwa manusia memiliki sumber dorongan agresif yang sifatnya otonomi dari dalam dirinya, suatu dorongan untuk melakukan kekerasan yang dalam kata- kata Lorenz menunjukkan ledakan tak tertahankan yang muncul teratur secara ritmis"(Lorenz, 1971).

Selain disebabkan dorongan insting dari dalam diri sendiri, perilaku kekerasan atau agresi juga dapat disebabkan oleh faktor belajar sosial. Teori Belajar Sosial (Social Learning) yang dimotori oleh Bandura menekankan bahwa kondisi lingkungan dapat memberikan dan memelihara respon-respon agresif pada diri seseorang. Asumsi dasar dari teori ini yaitu sebagian besar tingkah laku individu diperoleh dari hasil belajar melalui pengamatan atas tingkah laku yang ditampilkan oleh individu-individu lain yang menjadi model. Anak-anak yang melihat model orang dewasa agresif secara kosisten akan lebih agresif bila dibandingkan dengan anak-anak yang melihat model orang dewasa non agresif.

Asumsi psikologis ketiga adalah bahwa kebanyakan kekerasan terjadi sebagai respons terhadap frustrasi. Frustrasi merupakan gangguan dengan perilaku yang diarahkan oleh tujuan. Salah satu teori frustrasi-agresi yang paling berpengaruh dikemukakan Dollard dan koleganya di Yale pada 1939 (Dollard \& Miller, 1950). Dalil dasar dari teori ini adalah bahwa terjadinya perilaku kekerasan selalu mensyaratkan keberadaan frustrasi, dan sebaliknya keberadaan frustasi selalu menimbulkan beberapa bentuk kekerasan.

Bagian kedua dari dalil tersebut tidak bermaksud menunjukkan bahwa kekerasan merupakan satu-satunya respon terhadap frustrasi, melainkan bahwa frustrasi menghasilkan dorongan terhadap berbagai respons, salah satunya kekerasan. Bila respons non kekerasan tidak dapat menghilangan frustrasi, maka semakin besar probabilitas bagi dorongan kekerasan akhirnya menjadi dominan sehingga terjadi beberapa respons kekerasan.

Berdasarkan latar belakang di atas, penelitian ini bertujuan untuk mengetahui bentuk, dampak, dan penyebab tindak 
kekerasan guru terhadap siswa dalam interaksi belajar mengajar dari perspektif siswa. Hasil dari penelitian ini diharapkan dapat memberikan gambaran umum mengenai perspektif siswa terhadap fenomena kekerasan dalam pendidikan, terutama dengan guru sebagai pelaku.

\section{METODE}

Penelitian ini merupakan penelitian survey. Penelitian survey merupakan salah satu bentuk penelitian kuantitatif yang dapat digunakan untuk mengetahui pendapat, keyakinan, atau karakteristik suatu populasi (Creswell, 1994). Metode ini terutama unggul dalam hal efisiensi dalam mengumpulkan data dalam jumlah banyak.

Subjek dalam penelitian ini adalah siswa dari 5 SMP Negeri Surabaya dengan jumlah sampel 210 orang. Alat pengumpul data yang digunakan adalah angket yang terdiri dari 36 item berisi pertanyaan tertutup dan terbuka mengenai bentuk, dampak, dan penyebab tindak kekerasan yang dilakukan guru dalam interaksi belajar mengajar dari perspektif siswa. Data angket tersebut juga dapat digunakan untuk mengetahui frekuensi tindak kekerasan yang dilaporkan siswa. Angket tersebut dikembangkan sendiri oleh tim peneliti. Validitas isi dari angket diperoleh melalui penilaian panelis terhadap kesesuaian isi angket dengan teori yang digunakan. Angket juga diujicobakan pada 5 orang siswa
SMP dari sekolah yang berbeda, untuk melihat apakah item-item dalam angket dapat dipahami sesuai tujuan peneliti. Hasil revisi diperhatikan untuk menjadi masukan dalam memperbaiki item angket.

Data dianalisis menggunakan bantuan software SPPS versi 16 untuk mendapatkan data deskriptif mengenai frekuensi, bentuk, dampak, dan penyebab dari tindak kekerasan guru terhadap siswa dalam interaksi belajar mengajar.

\section{HASIL DAN PEMBAHASAN}

Berdasarkan angket yang disebar kepada 210 subyek, response rate atau respon terhadap angket adalah sebesar $85 \%$. Dengan demikian, terdapat sekitar 32 angket yang tidak dapat digunakan datanya, antara lain disebabkan angket tidak dikembalikan atau tidak diisi. Hasil dari angket akan disampaikan dalam bentuk tabel dan pie chart, yaitu mencakup bentuk-bentuk kekerasan yang dialami, penyebab, dan dampak dari tindak kekerasan guru terhadap murid, serta ringkasan yang menggambarkan secara umum frekuensi terjadinya kekerasan dari subyek penelitian, dan secara lebih spesifik, paparan data mengenai perbedaan frekuensi antara siswa laki-laki dan perempuan yang melaporkan tindak kekerasan guru yang pernah mereka alami. Berikut adalah ringkasan dari bentuk kekerasan verbal yang dialami siswa.

Tabel 1. Ringkasan respon siswa terhadap bentuk kekerasan verbal yang pernah dialamibentuk kekerasan verbal

\begin{tabular}{|ll|c|c|c|c|}
\hline \multicolumn{5}{|c|}{ Bentuk Kekerasan Verbal } \\
\hline & & Frequency & Percent & Valid Percent & Cumulative Percent \\
\hline Valid & malas kamu & 24 & 13.5 & 20.5 & 20.5 \\
& goblok kamu & 30 & 16.9 & 25.6 & 46.2 \\
& kurang ajar kamu & 2 & 1.1 & 1.7 & 47.9 \\
& lain-lain & 2 & 1.1 & 1.7 & 49.6 \\
& tidak pernah & 59 & 33.1 & 50.4 & 100.0 \\
& Total & 117 & 65.7 & 100.0 & \\
Missing & System & 61 & 34.3 & & \\
Total & & $\mathbf{1 7 8}$ & $\mathbf{1 0 0 . 0}$ & & \\
\hline
\end{tabular}


Berdasarkan tabel tersebut, maka dapat disimpulkan bahwa bentuk-bentuk kekerasan verbal yang dialami subyek antara lain dimarahi dengan kata-kata 'malas kamu' sebesar 13,5\%; 'goblok kamu' sebesar 16,9\%; 'kurang ajar kamu' sebesar 1\%; lalu lain-lain sebesar $1 \%$. Bentuk kekerasan verbal lain-lain antara lain dipanggil dengan nama orangtua dan memanggil dengan nama lain yang tidak sesuai dengan nama aslinya. Sebesar 33\% mengatakan tidak pernah mengalami bentuk kekerasan ini. Selanjutnya, sekitar 34\% subyek tidak memberi respon pada item ini.

Gambar 1. Ringkasan respon siswa terhadap kekerasan verbal yang dialami

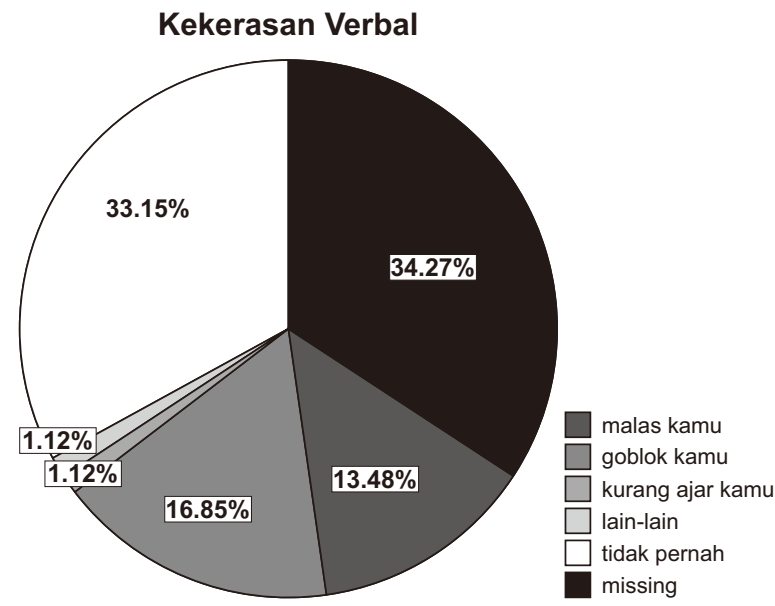

Selanjutnya adalah bentuk kekerasan psikologis, termasuk di dalamnya adalah pengabaian dan ancaman.
Berdasarkan tabel di atas, dapat diketahui bahwa sekitar $11 \%$ siswa pernah mengalami kekerasan psikologis berupa pengabaian atau tidak diperdulikan; sekitar $14 \%$ siswa melaporkan pernah diancam, sementara hampir 35\% mengatakan tidak pernah mengalami bentuk kekerasan ini. Sementara itu, sebesar $40 \%$ subyek tidak memberi respon pada item ini. Ringkasan data di atas diilustrasikan dalam bentuk chart pada Gambar 2

Gambar 2. Ringkasan respon siswa terhadap kekerasan psikologis yang dialami

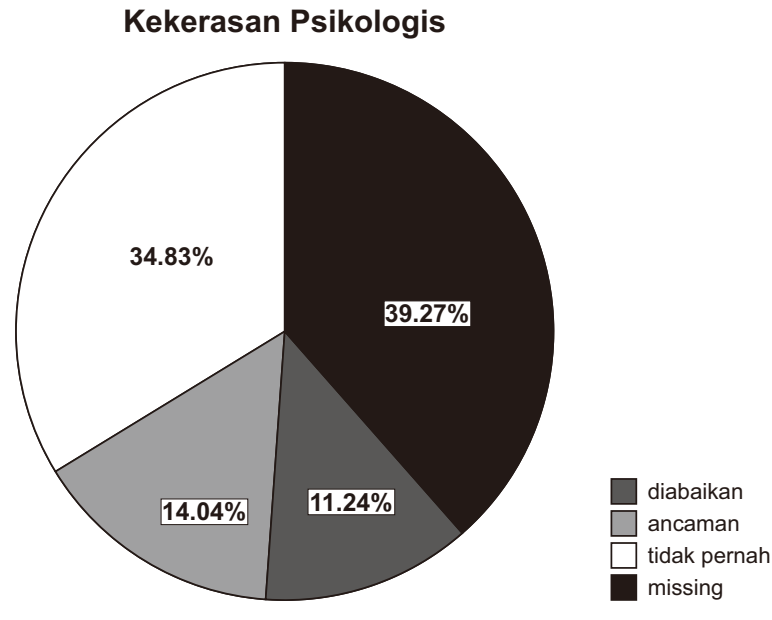

Bentuk kekerasan yang ketiga adalah kekerasan fisik. Berikut adalah ringkasan hasil respon siswa terhadap kekerasan fisik yang dialami (pada halaman selanjutnya).

Tabel 2. Ringkasan respon siswa terhadap kekerasan psikologis yang pernah dialami

\begin{tabular}{|ll|c|c|c|c|}
\hline \multicolumn{5}{|c|}{ Kekerasan Psikologis } \\
\hline \multirow{2}{*}{ Valid } & diabaikan & 20 & 11.2 & 18.7 & 18.7 \\
& ancaman & 25 & 14.0 & 23.4 & 42.1 \\
& tidak pernah & 62 & 34.8 & 57.9 & 100.0 \\
& Total & 107 & 60.1 & 100.0 & \\
Missing & System & 71 & 39.9 & & \\
Total & & $\mathbf{1 7 8}$ & $\mathbf{1 0 0 . 0}$ & & \\
\hline
\end{tabular}


Tabel 3. Ringkasan respon siswa terhadap kekerasan fisik yang pernah dialami

\begin{tabular}{|ll|c|c|c|c|}
\hline \multicolumn{5}{|c|}{ Bentuk Kekerasan Fisik } \\
\hline Valid & menjewer & Frequency & Percent & Valid Percent & Cumulative Percent \\
& mencubit & 11 & 6.2 & 22.9 & 22.9 \\
& mendorong kepala & 3 & 3.9 & 14.6 & 37.5 \\
& tidak pernah & 27 & 1.7 & 6.2 & 43.8 \\
& Total & 48 & 27.0 & 100.0 & 100.0 \\
Missing & System & 130 & 73.0 & & \\
Total & & $\mathbf{1 7 8}$ & $\mathbf{1 0 0 . 0}$ & & \\
\hline
\end{tabular}

Tabel di atas menunjukkan sebesar $6,2 \%$ siswa menyatakan pernah dijewer, sementara hampir $4 \%$ menyatakan pernah dicubit, sisanya, sebesar hampir $2 \%$ menjawab pernah didorong kepalanya. Sebesar $15 \%$ siswa menjawab tidak pernah mengalami kekerasan fisik, dan $73 \%$ subyektidak merespon item ini. Ringkasan data di atas diilustrasikan dalam bentuk chart pada Gambar 3 .

Selanjutnya, laporan mengenai jumlah kejadian yang muncul di 5 SMPN Surabaya yang menjadi sampel penelitian ini disampaikan dalam ringkasan tabel 4 berikut ini.
Gambar 3. Ringkasan respon siswa terhadap bentuk kekerasan fisik yang dialami

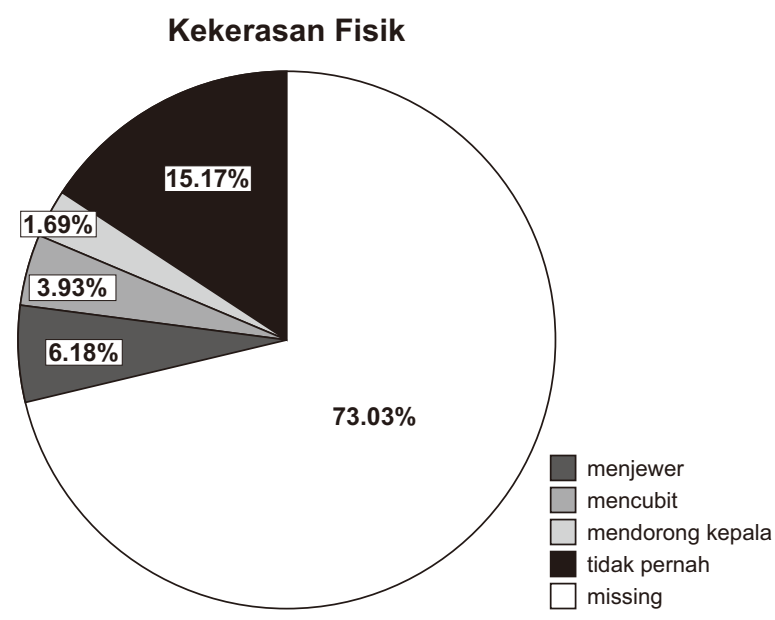

Tabel 4. Ringkasan jumlah kejadian yang dilaporkan siswa terkait tindak kekerasan yang pernah dialami

\begin{tabular}{|ll|c|c|c|c|}
\hline \multicolumn{5}{|c|}{ Berapa Kali } \\
\hline \multirow{4}{*}{ Valid } & kekerasan verbal & Frequency & Percent & Valid Percent & Cumulative Percent \\
& kekerasan psikologis & 82 & 32.6 & 35.8 & 35.8 \\
& kekerasan fisik & 22 & 12.4 & 13.6 & 86.4 \\
& Total & 162 & 91.0 & 100.0 & \\
Missing & System & 16 & 9.0 & & \\
Total & & $\mathbf{1 7 8}$ & $\mathbf{1 0 0 . 0}$ & & \\
\hline
\end{tabular}

Berdasarkan data di atas, diketahui bahwa tindak kekerasan yang dilakukan guru kepada murid dalam interaksi belajarmengajar berupa kekerasan verbal muncul sebesar 32,6\% atau sekitar 58 kejadian, sementara $46 \%$ atau sekitar 82 kejadian merupakan bentuk kekerasan psikologis, dan $12 \%$ atau sekitar 22 kejadian merupakan kekerasan fisik. Dengan demikian, dari 5 SMPN di Surabaya yang menjadi sampel 
penelitian, kejadian tindak kekerasan guru terhadap murid muncul dalam berbagai bentuk muncul hingga $91 \%$ atau 162 kejadian.

Gambar 4. Ringkasan jumlah kejadian yang dilaporkan siswa terkait tindak kekerasan yang pernah dialami

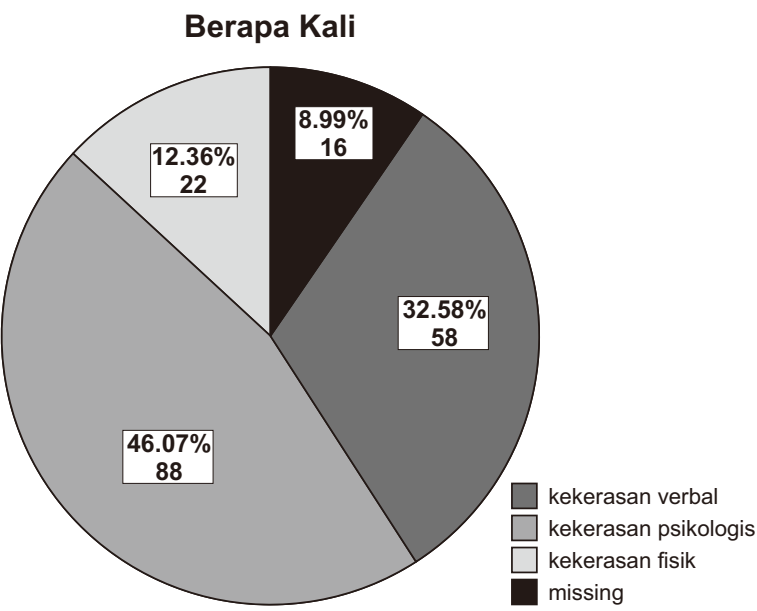

Secara umum, gambaran frekuensi siswa laki-laki dan perempuan yang pernah mengalami tindak kekerasan digambarkan dalam tabel 5.

Berdasarkan data tabel 5 di bawah, diketahui bahwa siswa laki-laki yang melaporkan pernah mengalami tindak kekerasan guru terhadap siswa dalam berbagai bentuk adalah sebesar 24,7\%, sementara perempuan lebih banyak, yaitu mencapai hampir $63 \%$. Lebih jelasnya, data tersebut ditampilkan dalam bentuk chart seperti pada Gambar 5.
Gambar 5. Ringkasan frekuensi siswa laki-laki dan perempuan yang mengalami tindak kekerasan

\section{Frekuensi berdasar Jenis Kelamin}

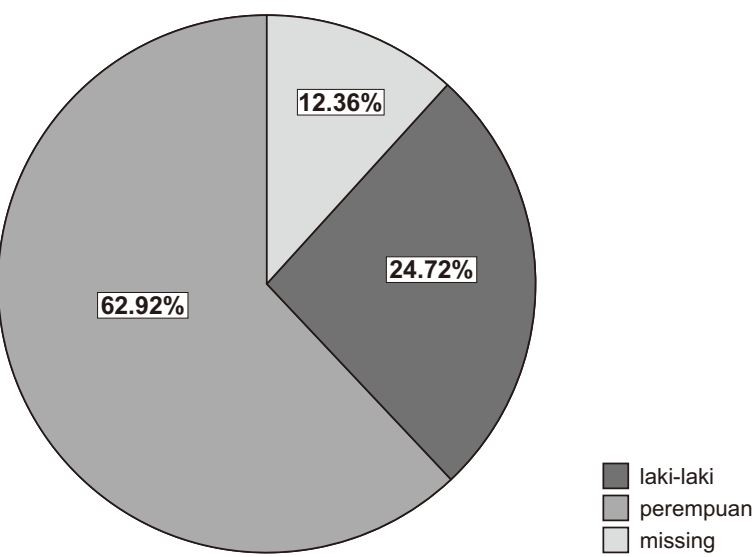

Selanjutnya, data angket juga mengungkap alasan atau penyebab munculnya tindak kekerasan guru terhadap siswa menurut siswa itu sendiri. Tabel 6 menampilkan ringkasan data respon siswa.

Berdasarkan tabel 6 (halaman berikut) $11,8 \%$ siswa menyatakan tidak mengetahui alasan dilakukannya tindak kekerasan tersebut, sementara sebesar $29 \%$ siswa mengakui bahwa sebab munculnya tindakan tersebut karena dipicu perilaku mereka sendiri. Selanjutnya, temperamen atau watak guru disebutkan oleh $2 \%$ siswa sebagai penyebab tindak kekerasan. Selain itu, 35\% jawaban siswa beragam, antara lain karena siswa ramai di kelas, malas, dan tidak memperhatikan. Gambar 6 berikut menampilkan ringkasan data respon siswa dalam bentuk chart.

Tabel 5. Ringkasan frekuensi siswa laki-laki dan perempuan yang pernah mengalami tindak kekerasan

\begin{tabular}{|ll|c|c|c|c|}
\hline \multicolumn{5}{|c|}{ Frekuensi berdasar Jenis Kelamin } \\
\hline & & Frequency & Percent & Valid Percent & Cumulative Percent \\
\hline Valid & laki-laki & 44 & 24.7 & 28.2 & 28.2 \\
& perempuan & 112 & 62.9 & 71.8 & 100.0 \\
& Total & 156 & 87.6 & 100.0 & \\
Missing & System & 22 & 12.4 & & \\
Total & & $\mathbf{1 7 8}$ & $\mathbf{1 0 0 . 0}$ & & \\
\hline
\end{tabular}


Tabel 6. Ringkasan respon siswa mengenai penyebab terjadinya tindak kekerasan

\begin{tabular}{|ll|c|c|c|c|}
\hline \multicolumn{5}{|c|}{ Penyebab alasan } \\
\hline Valid & tidak tahu & Frequency & Percent & Valid Percent & Cumulative Percent \\
& salah saya & 52 & 11.8 & 15.0 & 15.0 \\
& temperamen guru & 4 & 29.2 & 37.1 & 52.1 \\
& lain lain & 63 & 35.4 & 45.0 & 55.0 \\
& Total & 140 & 78.7 & 100.0 & 100.0 \\
Missing & System & 38 & 21.3 & & \\
Total & & $\mathbf{1 7 8}$ & $\mathbf{1 0 0 . 0}$ & & \\
\hline
\end{tabular}

Gambar 6. Ringkasan respon siswa mengenai penyebab terjadinya tindak kekerasan

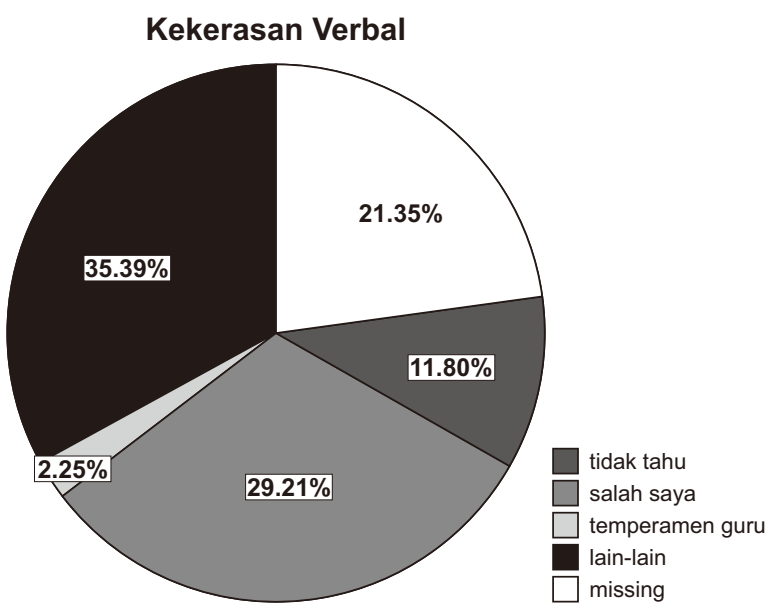

Data selanjutnya yang diungkap adalah mengenai dampak terhadap perasaan siswa sebagai akibat dari tindak kekerasan yang dilakukan guru. Tabel 7 menampilkan ringkasan data angket siswa.

Berdasarkan tabel di bawah, dapat diketahui bahwa hampir 3\% siswa merasa minder akibat tindakan yang dilakukan guru terhadap mereka; sebesar 38\% merasa sakit hati; 49\% merasa marah; 5\% merasa sedih, dan hampir $1 \%$ mengatakan ingin balas dendam. Selanjutnya, kurang-lebih 4\% siswa memberi jawaban beragam, dimana sebagian besar mengatakan biasa saja. Gambar 7 menampil-kan ringkasan data respon siswa dalam bentuk chart.

Berdasarkan paparan data di atas, dapat diketahui bahwa tindak kekerasan guru

Tabel 7. Ringkasan respon siswa mengenai dampak tindak kekerasan guru terhadap perasaan siswa

\begin{tabular}{|ll|c|c|c|c|}
\hline \multicolumn{5}{|c|}{ bagaimana perasaan } \\
\hline & Frequency & Percent & Valid Percent & Cumulative Percent \\
\hline Valid & minder & 5 & 2.8 & 2.8 & 2.8 \\
& sakit hati & 68 & 38.2 & 38.2 & 41. \\
& marah & 87 & 48.9 & 48.9 & 89.9 \\
& sedih & 9 & 5.1 & 5.1 & 94.9 \\
& balas dendam & 1 & .6 & .6 & 95.5 \\
& lain & 8 & 4.5 & 4.5 & 100.0 \\
Total & & $\mathbf{1 7 8}$ & $\mathbf{1 0 0 . 0}$ & $\mathbf{1 0 0 . 0}$ & \\
\hline
\end{tabular}


terhadap murid yang muncul atau dilaporkan mencapai 91\% atau sebanyak 162 kejadian. Angka ini tergolong tinggi, yaitu 162 kejadian dari 178 respon subyek penelitian. Walaupun demikian, sifat dari angket yang digunakan dalam penelitian ini memungkinkan adanya multi-respon; artinya, subyek atau responden penelitian dapat memberikan lebih dari satu macam respon terhadap satu item. Seorang subyek mungkin mengalami bentuk kekerasan verbal, sekaligus juga kekerasan psikologis, ataupun kekerasan fisik.

Adapun bentuk-bentuk kekerasan yang dapat teridentifikasi adalah bentuk kekerasan verbal, termasuk di dalamnya adalah memberi julukan yang tidak disukai, memanggil dengan nama orangtua, serta memanggil dengan nama lain yang tidak sesuai, memberi label dengan menyebut 'malas', 'goblok', dan 'nakal'. Bentuk yang kedua adalah bentuk kekerasan psiko-logis, seperti mengabaikan atau tidak memperdulikan, serta melontarkan kata-kata yang tujuannya mengancam atau mengintimidasi, seperti 'awas kamu'. Selanjutnya, bentuk yang ketiga adalah kekerasan fisik, seperti menjewer, memukul, serta mendorong kepala.

Data juga menunjukkan bahwa kasuskasus tindak kekerasan yang dilakukan guru, lebih banyak dilaporkan oleh siswa perempuan dibandingkan siswa laki-laki. Hal ini tidak dapat serta merta menggambarkan fenomena sesungguhnya; bahwa siswa lakilaki meng-alami tindak kekerasan yang lebih sedikit dibandingkan perempuan. Beberapa hal yang dapat menjelaskan hal tersebut antara lain; 1) siswa laki-laki cenderung tidak melaporkan berbagai bentuk atau tindak kekerasan yang mereka alami, 2) siswa perempuan lebih banyak berinteraksi dengan guru mereka dibandingkan siswa laki-laki, sehingga memperbesar kemungkinan mereka menjadi obyek kekerasan guru; 3) siswa perempuan merupakan obyek yang lebih rentan terhadap tindak kekerasan guru; 4) siswa perempuan lebih subyektif dalam menilai perilaku guru, dan dengan demikian, keliru memaknai perilaku guru sebagai bentuk kekerasan atau tindakan yang secara sengaja bertujuan menyakiti mereka. Asumsiasumsi tersebut memerlukan pengujian lebih lanjut.

Penelitian menunjukkan bahwa laki-laki cenderung lebih enggan melaporkan atau mengekspresikan hal-hal yang terjadi pada mereka dibandingkan perempuan. Hal ini salah satunya dapat disebabkan oleh faktor budaya, dimana umumnya anak laki-laki dididik untuk meyakini bahwa mereka memiliki kontrol terhadap lingkungan dan dapat mengambil tanggung jawab terhadap apa yang terjadi pada mereka (Kring, dkk, 2010).

Sejalan dengan pendapat tersebut, Back \& Lips (1998) menemukan bahwa laki-laki, dibandingkan dengan perempuan, cenderung memberi tanggung jawab yang lebih besar pada korban dalam kasus-kasus kekerasan. Perilaku 'mengadu' atau melapor pada orang yang lebih dewasa mengenai apa yang terjadi pada mereka juga sering dianggap sebagai bentuk perilaku yang 'tidak jantan' dan tidak pantas dilakukan anak laki-laki. Oleh sebab itu, perilaku diam atau tidak melapor dianggap lebih baik daripada mengadu. Sebaliknya, anak-anak perempuan kerap merasa lebih bebas untuk mengekspresikan atau melapor-kan apa yang mereka rasakan. Selain itu, Gustafson (1998) juga menemukan bahwa perbedaan gender berpengaruh pada penilaian terhadap realita. Laki-laki dan perempuan memiliki cara pandang atau persepsi yang subyektif terhadap realita, termasuk bagaimana menilai resiko lingkungan terhadap mereka.

Di sisi lain, perbedaan gender juga kerap menjadi perhatian dalam penelitianpenelitian survey, sebab sering ditemukan perbedaan respon yang mencolok antara lakilaki dan perempuan. Secara umum, laki-laki cenderung memberikan respon yang lebih rendah terhadap angket dibandingkan perempuan, sehingga missing data lebih banyak terjadi pada responden laki-laki daripada perempuan (Cull, dkk, 2005; 
Korkeila, dkk, 2001). Dengan demikian, perbedaan gender perlu mendapat perhatian dalam menginterpretasi hasil-hasil penelitian survey.

Selanjutnya, penyebab munculnya tindak kekerasan guru terhadap siswa menurut survey diantaranya adalah karena kesalahan yang dilakukan siswa, temperamen guru, dan berbagai alasan lain yang merujuk pada perilaku siswa yang tidak disukai guru, seperti perilaku malas, ramai di dalam kelas, tidak memperhatikan, serta alasan yang tidak diketahui siswa. Berkaitan dengan hal tersebut, diketahui pula apa yang dirasakan siswa sebagai dampak atau akibat dari tindak kekerasan guru terhadap mereka. Siswa diantaranya mengaku merasa minder atau rendah diri, marah, sakit hati, sedih, dan ingin balas dendam. Akan tetapi, ada pula siswa yang mengatakan biasa saja, atau dengan kata lain, tidak menganggap serius tindakan guru terhadap mereka.

Terdapat beberapa kemungkinan yang dapat menjelaskan mengapa siswa merasa 'biasa saja' dalam menyikapi tindakan guru terhadap mereka. Pertama, siswa tidak menyadari bahwa tindakan tersebut termasuk tindakan yang tidak wajar, terutama dalam dunia pendidikan. Hal tersebut dimungkinkan dengan maraknya tayangan kekerasan di media-media massa, termasuk televisi, internet, dan game atau permainan virtual yang menjadikan siswa terbiasa dengan perilakuperilaku tersebut di lingkungan mereka.

Alasan yang kedua, siswa merasa bahwa mereka layak mendapat hukuman atas perilaku mereka. Sebagian siswa mungkin memaknai tindak kekerasan yang mereka alami sebagai bentuk hukuman atas perilaku mereka yang tidak pada tempatnya. Hal ini terlihat dari kemampuan siswa untuk mengidentifikasi perilaku-perilaku yang memicu munculnya tindak kekerasan tersebut. Dengan demikian, siswa sebenarnya dapat mengenali perilaku yang secara normatif salah, akan tetapi ada faktor-faktor lain yang menyebabkan mereka tidak dapat mengendalikan diri dan menghindari perilaku-perilaku tersebut. Salah satunya dapat disebabkan kurang efektifnya pengelolaan kelas, yang dapat dipengaruhi oleh tidak memadainya rasio antara guru dengan siswa dalam satu kelas. Hal tersebut senada dengan pendapat Pengawas Sekolah yang memberi rekomendasi mengenai karakter sekolah yang umumnya memiliki lebih banyak masalah kekerasan guru terhadap siswa, salah satu yang paling utama adalah sekolah-sekolah yang padat siswanya. Rata-rata siswa per kelas pada 5 SMPN yang menjadi sampel penelitian ini berkisar antara 30 hingga 50 orang. Padatnya siswa dalam satu kelas, dapat memicu berbagai permasalahan dalam upaya pengelolaan kelas yang dapat berdampak pada perilaku siswa.

Lebih lanjut lagi, sebagian siswa mengatakan tidak mengetahui alasan munculnya tindak kekerasan guru. Hal ini antara lain dapat dijelaskan sebagai berikut. Pertama, siswa keliru memaknai atau menilai perilaku guru terhadap mereka. Contohnya, perilaku mengabaikan atau tidak memperdulikan mungkin dilakukan guru untuk mengabaikan perilaku tertentu yang ditunjukkan siswa. Hal tersebut dilakukan misalnya, untuk menghindari penguatan yang keliru terhadap perilaku siswa. Memberikan reaksi terhadap perilaku siswa dapat menjadi bentuk penguatan yang keliru yang menyebabkan suatu perilaku berulang, padahal perilaku tersebut tidak diharapkan. Akan tetapi, siswa mungkin menilai bentuk pengabaian tersebut sebagai pengabaian terhadap diri mereka secara pribadi, karena alasan-alasan yang pribadi pula.

Kemungkinan kedua, sebagian siswa gagal mengenali perilaku mereka sendiri yang mungkin memicu munculnya reaksi guru. Hal ini berkaitan pula dengan kemungkinan ketiga, yaitu kemampuan guru dalam mengomunikasikan harapan mereka terhadap perilaku siswa, serta mendorong terjadinya perubahan perilaku. Sebagian guru mungkin beranggapan bahwa bentuk tindak kekerasan 
sebagai bentuk hukuman merupakan metode yang efektif untuk mengurangi atau menghilangkan perilaku negatif siswa. Di sisi lain, siswa kerap memerlukan penjelasan mengapa suatu hukuman dikenakan pada mereka, sebab mereka tidak mengetahui bahwa perilaku mereka salah, atau mereka tidak memiliki alternatif perilaku lain yang lebih tepat dalam menghadapi suatu situasi. Contoh, siswa menjadi cenderung ramai di kelas atau mencari kesibukan sendiri ketika tidak memahami penjelasan guru atau merasa tidak diperhatikan. Siswa perlu diberi strategi yang lebih tepat dalam menghadapi situasi tersebut. Kemampuan guru dalam berkomunikasi secara efektif dengan siswa juga memegang peranan penting.

Berdasarkan paparan di atas, dapat disimpulkan bahwa hasil penelitian survey ini kurang memadai untuk mendapat penjelasan menyeluruh mengenai tindak kekerasan guru terhadap siswa. Adanya perbedaan respon yang cukup besar antara siswa laki-laki dan perempuan, mengindikasikan perlunya memahami pengaruh faktor jenis kelamin dalam memahami fenomena ini. Penelitian lanjutan mengenai hal tersebut dapat memperkaya hasil penelitian ini.

Penelitian mengenai penyebab dari tindak kekerasan guru terhadap murid juga tidak dapat dijelaskan dengan memadai jika hanya memperhitungkan perspektif atau sudut pandang siswa. Selain itu, keterbatasan angket sebagai alat utama pengumpul data dalam penelitian survey, terutama berdampak pada kedalaman informasi yang diperoleh. Oleh sebab itu, penelitian lanjutan diperlukan untuk memperdalam pemahaman terhadap fenomena ini. Penelitian kualitatif dengan metode wawancara mendalam terhadap guru dan siswa dapat menjadi pendekatan yang lebih tepat untuk tujuan tersebut.

\section{DAFTAR PUSTAKA}

Back, S., \& Lips, H.M. (1998). Child Sexual Abuse: Victim Age, Victim Gender, and Observer Gender as Factors Contributing to Attributions of Responsibility. Child Abuse and Neglect 22(12), hlm. 1239-1252

Berkowitz, L. (1993). Emotional Behavior. Mc. Graw-Hill Inc.

Covey, S. (1998). The 7 Habits of Highly Effective Teens. New York: A Fireseide Book.

Creswell, J.W. (1994). Research Design: Qualitative \& Quantitative Approaches. London: Sage Publications Ltd.

Cull, W.L., O'Connor, K.G., Sanford, S., Tang, S.S. (2005). Response rates and response bias for 50 surveys of pediatricians. Health Service Research 40(1), hlm. 213-226

Dollard, J. \& Miller, N.E. (1950). Personality and Psychotherapy. New York: Mc.Graw-Hill.
Gilligan, J. (1996). Violence as Tragedy. New York: Vintage Books.

Gustafson, P.E. (1998). Gender differences in risk perception: Theoretical and methodological perspectives. Risk Analysis 18(6)

Jawa Pos, 17 Oktober 1997 , 25 April 2002 27 April 2002 21 November 2007

Korkeila, K., Suominen, S., Ahvenaine, J., Ojanlatva, A., Rautava, P., Helenius, H., Koskenvuo, M. (2001). Nonresponse and related factors in a nation-wide health survey. European Journal of Epidemiology 17(11), hlm.991-999

Kedaulatan Rakyat, 13 Oktober 1997. Kompas, 27 Juli 2005.

Media Indonesia, 28 Nopember 2006. Smith, J.M. \& Lusterman, D.D. (1979). The Teacher As Learning Fasilitator: 
JURNAL PSIKOLOGI: TEORI \& TERAPAN, Vol. 1, No. 2, Pebruari 2011

Psychology and The Educational Process. California: Wadsworth Publishing Company, Inc. 